\title{
Oral contraception among risk factors for women with ischemic stroke
}

\author{
Carla Signor PALUDO ${ }^{1}$ (D) Amanda SACHETTI ${ }^{1}$ (D), Maiara Soares da PAIXÃO ${ }^{1}$ (D) \\ ${ }^{1}$ Hospital de Clínicas de Passo Fundo, \\ Corresponding author: Paludo CS, carlasignor@hotmail.com \\ Submitted: 13-12-2020 Resubmitted: 09-03-2021 Accepted: 09-03-2021
}

Peer review: Hilris Rocha e Silva, Karina Aparecida Resende and Emília Vitória Silva

\begin{abstract}
Objective: To evaluate the frequency of use of oral contraceptives and other risk factors among women with ischemic stroke seen at a hospital in the northern region of the state of Rio Grande do Sul. Methods: Prospective, cross-sectional study. The population was characterized by patients admitted with a diagnosis of ischemic stroke during a period from March to August 2019 and the sample by female patients found in the population. The data were collected through an individual interview using a questionnaire developed by the researchers and tabulated for further analysis. All analyzes were performed using the statistical program Bioestat 5.0, considering $p=0.05$. Results: In the characterization of the sample, an average age of 68.2 years was observed. The occurrence of gender was $52.4 \%$ for women. The mean hospital stay was $12.2 \pm$ 8.91 days. Outcome of hospital discharge was $89.1 \%$. The mean value of body mass index was $25 \pm 4.89 \mathrm{~kg} / \mathrm{m}^{2}$, with an average of $27.4 \mathrm{~kg} / \mathrm{m}^{2}$ in patients who used oral contraceptives and $25.23 \mathrm{~kg} / \mathrm{m}^{2}$ in patients who did not use oral contraceptives. The sample had a $34.5 \%$ incidence of oral contraceptive use. The average age of those who used oral contraceptives was 62.4 years and of the patients who did not use it was 70.3 years. Conclusion: The study showed a high use of oral contraceptives in the sample, with percentage values very close to other factors evaluated, thus showing itself as a probable risk factor for the development of ischemic stroke.
\end{abstract}

Keywords: stroke; contraceptive agents; neurology; risk factors; women's health.

\section{Anticoncepcional oral entre fatores de risco para mulheres com avc isquêmico}

\section{Resumo}

Objetivo: Avaliar a frequência de uso de anticoncepcional oral e outros fatores de risco entre mulheres com acidente vascular cerebral isquêmico atendidos em um hospital da região norte do estado do Rio Grande do Sul. Métodos: Estudo seccional prospectivo, observacional, longitudinal. A população se caracterizou por pacientes que internaram com diagnóstico de acidente vascular isquêmico durante um período de março a agosto de 2019 e a amostra por pacientes do sexo feminino encontradas na população. Os dados foram coletados a partir de uma entrevista individual utilizando um questionário desenvolvido pelos pesquisadores e tabelados para posterior análise. Todas as análises foram realizadas utilizando o programa estatístico Bioestat 5.0, considerando $p=0,05$. Resultados: $\mathrm{Na}$ caracterização da amostra, foi observado uma média de idade de 68,2 anos. A ocorrência de gênero foi de 52,4\% para mulheres. 0 tempo médio de internação hospitalar foi de 12,2 $\pm 8,91$ dias. Desfecho de alta hospitalar foi 89,1\%. O valor médio de índice de massa corporal foi $25 \pm 4,89 \mathrm{~kg} / \mathrm{m}^{2}$, sendo média de $27,4 \mathrm{~kg} / \mathrm{m}^{2}$ nas pacientes que usaram anticoncepcional oral e $25,23 \mathrm{~kg} / \mathrm{m}^{2}$ nas pacientes que não utilizaram anticoncepcional oral. A amostra apresentou 34,5\% de incidência de uso de anticoncepcional oral. A média de idade de quem utilizou anticoncepcional oral foi 62,4 anos e das pacientes que não utilizaram foi 70,3 anos. Conclusão: 0 estudo evidenciou elevado uso de anticoncepcional oral na amostra, com valores percentuais muito próximos a outros fatores avaliados, deste modo mostrou-se como provável fator de risco para o desenvolvimento de acidente vascular cerebral isquêmico.

Palavras-chave acidente vascular cerebral; anticoncepcionais; neurologia; fatores de risco; saúde da mulher.

\section{Introduction}

Cerebrovascular accident (CVA) is characterized by the onset of neurological deficits according to the region and the cerebral circulation that was involved in the event. It can be classified as hemorrhagic (HCVA) or ischemic (ICVA), which is seen as the most common among all types of CVA. Due to lack of supply or interruption of blood flow caused by numerous factors, the ICVA causes cell death of the brain tissue and, as a consequence, important sequelae for the affected individuals. ${ }^{1}$ 
In the general population, this serious event is linked to several well-established risk factors such as systemic arterial hypertension $(\mathrm{SAH})$, dyslipidemia, smoking, diabetes mellitus (DM), atrial fibrillation and previous CVA, among others. ${ }^{2}$ With regard to the female population, other conditions can favor CVA, such as migraine (especially with aura) and exposure to exogenous sex hormones, such as estrogens in oral contraceptives (OCs), hormone replacement, ${ }^{3-7}$ pregnancy, age at menarche and menopause. $^{2}$

Despite the benefits of using OC, a number of studies show that the use of this hormonal contraceptive increases the CVA risk, ${ }^{2,8}$ especially if it is in current use, in addition to the progressive increase in chances according to the duration of use. ${ }^{9}$ When associated with other risk factors such as smoking, SAH, obesity or migraine, this outcome is more likely to occur compared to women who do not use OC. ${ }^{4,10}$ Entities such as the WHO already produce medical materials that indicate the eligibility criteria for use of $O C$ with caution or restriction according to the pathology presented by the patient, due to an increased risk of cardiovascular problems, reinforcing the idea of this study.

The female sex hormones used for the composition of OCs can have deleterious effects on the cardiovascular system, such as deep vein thrombosis (DVT), myocardial infarction and CVA. The blood vessels have estrogen and progesterone receptors in all their layers, which, when activated, have thrombogenic characteristics, having the effect of increasing coagulation factors, such as prothrombin, for example. ${ }^{6}$ The aim of this study was to evaluate the use frequency of oral contraceptives (OCs) and other risk factors among women with ischemic cerebrovascular accident (ICVA) treated at a hospital in the northern region of the state of Rio Grande do Sul.

\section{Methods}

This is a prospective and observational study, with a crosssectional design. The project was elaborated according to the Regulatory Guidelines and Rules for research involving human beings and presented to the Ethics and Research Committee, under number 3,270,442 and approved with CAAE number 08965319.6.0000.5342. Data collection took place after authorization and signature of the Free and Informed Consent Form (FICF) by the patients or their guardians, and was carried out during the period from March to August 2019 (6 months) in a hospital in the northern region of the state of Rio Grande do Sul.

The study population was characterized by patients admitted to the emergency sector and CVA unit, treated by the hospital's neurology service with a diagnosis of ICVA from March to August 2019. The hospital where the study was conducted is classified as tertiary and is also a reference in the care of CVA patients in the northern region of the state. All adult patients (18 years of age or older) who were admitted to the institution with a CVA diagnosis were included in the population, and patients with hemorrhagic CVA were excluded. The sample extracted consisted of all the women from this population, which can be seen in Figure 1. The patients were selected through an active search in the CVA unit and through communication tools and institutional protocols that identified these patients.

Data were collected from an individual interview using a standard semi-structured questionnaire developed by the researchers,
Figure 1. Flowchart of patient entry

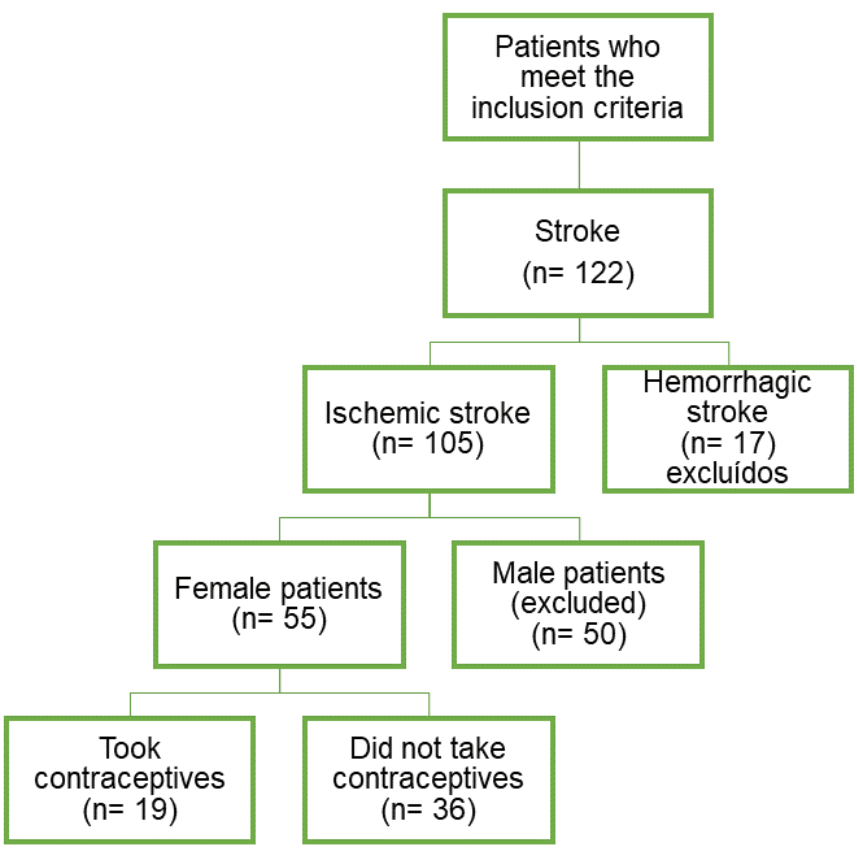

where epidemiological data were collected, as well as data identifying the type of CVA, on previous drug treatment and hormonal therapy, risk factors, BMI (Body Mass Index), mortality rate, length of hospitalization and frequency of ICU admissions. Other data, such as outcomes and length of hospitalization in the institution, were obtained through the patients' electronic medical records. The data were organized in a database by using the Microsoft Office Excel software for later statistical analysis.

For sample characterization, descriptive statistics were used, such as mean and standard deviation of the numerical variable, in addition to minimum and maximum values. Percentage values were also used to analyze the variables in terms of frequency, results that can be seen in Table 1. Data normality was tested and obtained through the Kolmogorov-Smirnov test. The comparison between the groups of interest that were patients who used OCs and patients who did not use them was carried out using the student's $t$ test. The nominal data were analyzed by means of the Chi-Square test. All the analyses were performed using the Bioestat 5.0 statistical program, considering $p=0.05$.

\section{Results}

From Table 1, in addition to other information, we can see the characterization of the sample, with the variables identified and their values. The mean age found was $68.2( \pm 13.76)$ and, among the most frequent comorbidities, we can mention SAH, DM, and cardiovascular diseases. In addition to these results, we find information regarding the outcome of the sample (discharge or death). We can also verify the frequency of the main risk factors observed in the sample, among them the use of continuous medications other than OCs, presenting a higher frequency among the patients, followed by smoking, use of OC, BMI variables (kg/ $\mathrm{m}^{2}$ ), and alcoholism, as well as their percentage values. 
Table 1. Characteristics of the patients and their hospitalization according to the use of contraception methods, Passo Fundo, $2019, \mathrm{n}=55$.

\begin{tabular}{|c|c|c|c|c|}
\hline \multirow{3}{*}{ Information } & \multirow{3}{*}{ All $\mathrm{N}=55$} & \multicolumn{2}{|c|}{ Use of oral contraception } & \multirow{3}{*}{ p-value } \\
\hline & & \multirow{2}{*}{$\begin{array}{l}\text { Yes } \\
\mathrm{N}=19\end{array}$} & \multirow{2}{*}{$\begin{array}{l}\text { No } \\
\mathrm{N}=36\end{array}$} & \\
\hline & & & & \\
\hline \multicolumn{5}{|l|}{ Sociodemographic } \\
\hline Age (years old) Mean (SD) & $68.2(13.8)$ & $62.4(16.1)$ & $70.3(11.7)$ & 0.069 \\
\hline \multicolumn{5}{|l|}{ Indicator of nutritional status } \\
\hline BMI (kg/m²) Mean (SD; range) & $25(4.9 ; 17.3-31.1)$ & $27.4(4.0)$ & $25.2(5.2)$ & 0.104 \\
\hline Underweight (below 18.5) n (\%) & $3(5.4)$ & & & \\
\hline Eutrophic (18.6 - 24.9) n (\%) & $22(40)$ & & & \\
\hline Overweight (25 - 29.9) n (\%) & $15(24.3)$ & & & \\
\hline Obesity Class I (30 - 34.9) n (\%) & $10(18.2)$ & & & \\
\hline \multicolumn{5}{|l|}{ Hospitalization data } \\
\hline Hospitalization time (days) Mean (SD) & $12.2(8.9$ & $11.7(7.5)$ & $14.22(13.3)$ & 0.369 \\
\hline Hospitalization time in ICU (days) & $6(10.9)$ & $10(2.5)$ & $10.67(4.6)$ & 0.774 \\
\hline \multicolumn{5}{|l|}{ Comorbidities $\mathrm{n}(\%)$} \\
\hline Systemic Arterial Hypertension & $43(78.2)$ & $12(63.2)$ & $31(86.1)$ & 0.059 \\
\hline Diabetes Mellitus & $17(31)$ & $2(10.5)$ & $15(41.7)$ & 0.017 \\
\hline Cardiovascular diseases & $17(31)$ & $6(32.2)$ & $11(30.6)$ & 0.937 \\
\hline Vascular diseases & $8(14.5)$ & $1(5.3)$ & $7(19.4)$ & 0.155 \\
\hline Respiratory diseases & $8(14.5)$ & $2(10.5)$ & $6(16.7)$ & 0.538 \\
\hline Neurological diseases & $10(18.2)$ & $5(26.3)$ & $5(13.9)$ & 0.255 \\
\hline Musculoskeletal diseases & $4(7.3)$ & $2(10.5)$ & $2(5.6)$ & 0.499 \\
\hline Oncological diseases & $4(7.3)$ & - & $4(11.1)$ & 0.131 \\
\hline Dyslipidemias & $6(10.9)$ & - & $6(16.7)$ & 0.059 \\
\hline Renal diseases & $1(1.8)$ & $1(5.3)$ & - & - \\
\hline \multicolumn{5}{|c|}{ Factors associated with the risk of cerebrovascular accident $n(\%)$} \\
\hline Smoking & $24(43.6)$ & $9(47.3)$ & $15(41.7)$ & 0.685 \\
\hline Alcoholism & $1(1.8)$ & - & $1(2.8)$ & 0.463 \\
\hline Use of oral contraception & $19(34.5)$ & & & \\
\hline Use of other continuous medications & $46(83.6)$ & $18(94.7)$ & $1(2.8)$ & 0.105 \\
\hline \multicolumn{5}{|l|}{ Outcome n (\%) } \\
\hline Discharge & $49(89.1)$ & $16(84.2)$ & $33(91.7)$ & 0.398 \\
\hline Death & $6(10.9)$ & $3(15.8)$ & $3(8.3)$ & 0.001 \\
\hline
\end{tabular}

BMI: Body Mass Index. ICU: Intensive Care Unit. SAH: Systemic Arterial Hypertension. DM: Diabetes Mellitus. BMI: Body Mass Index. OC: Oral Contraception. ICU: Intensive Care Unit. It was not possible to obtain information of the BMI values in 2 patients. $p$-value: Obtained through the Chi-Square test.

Table 1 also represents the specific results related to the use of OC: comparison between patients who used $O C$ and those who did not, relating to BMI (Body Mass Index) values, classified according to the World Health Organization, ${ }^{11}$ with length of hospitalization, hospitalization time in the Intensive Care Unit (ICU), and also the relationship between age and the occurrence of ICVA. This part of the results was obtained through the student's $t$ test.

\section{Discussion}

The mean age found in the sample was $68.2 \pm 13.8$ years old, which is very close to that found in the literature, ${ }^{12-15}$ with a range of 32 to 92 years old, the early age possibly being justified by the use of oral contraceptives as a risk factor associated with the female population specifically. ${ }^{3-7}$ Length of hospitalization varied from 4 to 43 days, with a mean of $12.2 \pm 8.9$ days with an increase proportionally related to hospital complications, such as infections by bacteria with a multidrug resistance profile, vascular problems related to possible sequelae of CVA and also the drug treatment used, very frequent motor and respiratory sequelae and often extremely debilitating in these patients, as found in the literature. ${ }^{12,13,18}$ As expected for ICVA patients, the outcome showed a high percentage of hospital discharge, ${ }^{12,13}$ with $89.1 \%$.

As expected, risk factors such as SAH and DM showed values around $78 \%$ and $31 \%$, respectively, consistent with the literature. ${ }^{2,15}$ In addition, when we relate $\mathrm{SAH}$ and $\mathrm{OC}$ use, we find results relevant for the study ( $p=0.059)$, since SAH is the main risk factor associated with the development of CVA. In addition to that, according to the Circle with the WHO medical eligibility criteria for the use of contraceptive methods, developed in 2015, the use of any type of combined $\mathrm{OC}$ is classified as follows: a method that must not be used in patients with SAH ( $>160 \mathrm{mmHg} />100 \mathrm{mmHg}$ ) and as: the use of the method is not recommended, unless other more suitable methods are not available for patients with controlled $\mathrm{SAH}$ or with values between $140-159 \mathrm{mmHg} / 90-99 \mathrm{mmHg} .{ }^{19}$ Herein noting important restrictions due to possible complications of contraception use and having SAH.

When DM and OC are related, we observe a relevant statistical value $(p=0.017)$, which can be justified by the more classic vascular pathology complications. In addition to that, the World Health Organization contraindicates the use of $O C$ in patients with DM due to the increased risk of developing CVA. ${ }^{4}$ In the 
same way, dyslipidemias appear with an important value in the results ( $p=0.059)$ and can also be explained by their more serious complications being acute myocardial infarction (AMI) and vascular accidents. ${ }^{20}$ The incidence of cardiovascular diseases appears as a third or later risk factor for the development of ICVA, ${ }^{14,15,16}$ different from what was found in this population with equally expressive numbers as DM (31\%).

The incidence of CVA events is changing over the years; more recent studies show values remarkably close to the percentages of men and women ${ }^{12,17}$ and, in others, higher values for women ${ }^{13,15}$ compatible with the values of $52.4 \%$ and $47.6 \%$ of women and men, respectively, found in the studied population. These results can be related to the increased use of OC accompanied by high risk factors for CVA such as migraine with aura and SAH, consequently increasing the incidence in the female gender, especially in women of childbearing age (up to 45 years old). ${ }^{4,7}$

In relation to $\mathrm{BMI}$, the mean value found was $25 \pm 4.89 \mathrm{~kg} / \mathrm{m}^{2}$ classified as excess weight, a value also found in some studies. ${ }^{14,21,22}$ The progressive increase in $\mathrm{BMI}$ in the population is consequently related to SAH and DM, which continue to be the main pathologies related to CVA risk. No statistically significant values were found when the $\mathrm{OC}$ and $\mathrm{BMI}$ factors were related.

Regarding oral contraception, its use was identified in $34.5 \%$ of the sample, a value that is compatible with the use prevalence in the Brazilian South region ${ }^{23}$. In view of the use of OC observed in the literature and evidenced in this study, some authors state that the use of OC must be observed and indicated with caution, mainly if the use is accompanied by other risk factors, such as migraine, DM, smoking, SAH, and history of previous CVA. 4,6,10

The length of hospitalization, as well as the hospitalization time in the ICU, did not present any statistical difference among the population that used or did not use contraception. Although the sample is reduced, it can be identified that the female population that used OC has a tendency to develop ICVA events a mean of 8 years earlier than women who did not use it. Corroborating the results found by Christo, with a mean age of 28.2 years old for patients using $\mathrm{OC}$ and a mean age of 42.2 for those not using OC. ${ }^{5}$

The limitations of the study include the collection of more specific data from the female population affected by ICVA, such as gestational history, classification of oral contraceptives used in categories (combined and simple hormones), history of migraines, family history of venous thrombosis, or classification of the sample by childbearing age. Such information of relevance for the study could present more concise and specific results about the main risk factors and a better characterization of the female population in Brazil.

Another study limitation was the fact that it was not possible to validate the semi-structured questionnaire developed for the research due to limited time to conduct data collection and the presentation of the results obtained.

\section{Conclusion}

The study evidenced the use of OC compatible with regional values in the sample but, despite this, we reveal a significant relationship between the use of $\mathrm{OC}$ and some pathologies that are important risk factors for the development of CVA, such as SAH and DM, showing that there is a relationship between them and that the indication of using an adequate contraceptive method is a decision that needs to be evaluated and indicated with great caution by the health professionals, always taking into account the patient's medical history and risk factors related to lifestyle. Considering the importance of the subject matter and bearing in mind that studies relating ICVA and specific risk factors for women in Brazil were not identified, further studies are still needed to confirm these results by correlating more specific data of the target population.

\section{Funding sources}

Ministry of Health, through Edict No. 11 of November 27 th, 2017 , which governs the granting of scholarships for Residencies in the Health Professional Area.

\section{Collaborators}

PCS: 1. Project conception or analysis and interpretation of data; 2. Article writing or critical review relevant to the intellectual content. SA: 2. Article writing or critical review relevant to the intellectual content. PMCS: 2. Conception and design or data analysis and interpretation.

\section{Conflicts of interest statement}

The authors declare that there are no conflicts of interest regarding this article.

\section{References}

1. Aguiar C. Avaliação de Acidente Vascular Cerebral em Tomografia Computadorizada Utilizando Algoritmo de Otimização de Formigas [Dissertação de Mestrado em engenharia elétrica]. Instituto Federal de Educação, Ciência e Tecnologia da Paraíba, João Pessoa, 2017.

2. Demel SL, Kittner S, Ley S et al. Stroke Risk Factors Unique to Women. J Am Heart Assoc. 2018;49 (3): 518-523.

3. Araújo MC, Silva MBF, Ponte KMA. Conhecimento e Riscos Para Acidente Vascular Cerebral Em Mulheres. Sanare 2018;17(02): 06-12.

4. Lima ACS, Martins LCG, Lopes MVO et al. Influence of hormonal contraceptives and the occurrence of stroke: integrative review. Rev Bras Enferm. 2017;70 (3).

5. Christo PP, Carvalho GM, Gomes Neto AP. Trombose de seios venosos cerebrais: estudo de 15 casos e revisão de literatura. Rev Assoc Med Bras 2010;56(3): 288-92.

6. FEBRASGO. Tromboembolismo venoso e contraceptivos hormonais combinados. Série orientações e recomendações. São Paulo 2016; 4(1).

7. Champaloux SW, Tepper NK, Monsour M, et al. Use of combined hormonal contraceptives among women with migraines and risk of ischemic stroke. Am J Obstet Gynecol 2017; 216:489 e1-7.

8. Roach RE, Helmerhorst FM, Lijfering WM, et al. Combined oral contraceptives: the risk of myocardial infarction and ischemic stroke. Cochrane Database of Systematic Reviews 2015; 8. 
9. Li F, Zhu L, Zhang J et al. Oral Contraceptive Use and Increased Risk of Stroke: A Dose-Response Meta-Analysis of Observational Studies. Front. Neurol 2019; 10:993.

10. Sacco S, Merki-Feld GS, AEgidius KL, Bitzer J et al. Hormonal contraceptives and risk of ischemic stroke in women with migraine: a consensus statement from the European Headache Federation (EHF) and the European Society of Contraception and Reproductive Health (ESC) J Headache Pain 2017; 18:108.

11. World Health Organization. Obesity: preventing and managing the global epidemic. Report of a WHO Consultation on Obesity. Geneva; 2000.

12. Mourão AM, Vicente LCC, Chaves TS et al. Perfil dos pacientes com diagnóstico de avc atendidos em um hospital de minas gerais credenciado na linha de cuidado. Revista Brasileira de Neurologia 2017;53(4).

13. Barella RP, Duran VA, Pires AJ et al. Perfil do atendimento de pacientes com acidente vascular cerebral em um hospital filantrópico do sul de santa catarina e estudo de viabilidade para implantação da unidade de AVC. Arq. Catarin Med. 2019 jan-mar; 48(1):131-143.

14. Sampaio RF, Gomes IC, Sternick EB. Cryptogenic Acute Ischemic Stroke: Assessment of the Performance of a New Continuous Long-Term Monitoring System in the Detection of Atrial Fibrillation. Arq Bras Cardiol. 2018; 111(2):122-131.

15. Sá BP, Grave MTQ, Périco E. Perfil de pacientes internados por Acidente Vascular Cerebral em hospital do Vale do Taquari/ RS. Rev Neurocienc 2014;22(3):381-387.

16. Gaudiano J, Graña D, Goñi M Co et al. Epidemiológica del ataque cerebro vascular en un hospital universitario. Rev. urug. Med. Interna 2019 (2): 24-31.

17. Barbosa RA, Vasconcelos TB, Sousa CT et al. Perfil dos pacientes adultos com acidente vascular encefálico tratados em uma clínica-escola de fisioterapia. Rev. Aten. Saúde, São Caetano do Sul 2017;15 (51) 5-10.

18. Moura MC, Casulari LA. Impacto da adoção de medidas inespecíficas no tratamento do acidente vascular cerebral isquêmico agudo em idosos: a experiência do Distrito Federal, Brasil. Rev Panam Salud Publica. 2015;38(1):57-63.

19. World Health Organization. Roda com os critérios médicos de elegibilidade da OMS para uso de métodos anticoncepcionais- atualização de 2015. Genebra: Organização Mundial da Saúde; 2018. Licença: CC BY-NC-SA 3.0 IGO.

20. Sá ACMGN et al. Factors associated with high LDL-Cholesterol in the Brazilian adult population: National Health Survey. Ciência \& Saúde Coletiva, 26(2):541-553, 2021

21. Vicente VS, Cabral NL, Nagel $V$ et al. Prevalence of obesity among stroke patients in five Brazilian cities: a cross-sectional study. Arq Neuropsiquiatr 2018;76(6):367-372

22. Mitchell AB, Cole JW, McArdle PF et al. Obesity Increases Risk of Ischemic Stroke in Young Adults. Stroke. 2015 June; 46(6): 1690-1692.

23. Farias MR, Leite SN, Tavares NULT et al. Utilização e acesso a contraceptivos orais e injetáveis no Brasil. Rev Saúde Pública 2016;50(supl 2):14s. 